\title{
SCIDOC
}

International Journal of Dentistry and Oral Science (IJDOS)

ISSN: 2377-8075

\section{Study Effect of Chlorhexidine - Honey and Propolis on Lactobacillus in Children. In Vitro Study}

Research Article

\author{
Abdulrhmanalkhaled ${ }^{1 *}$, Faekbadr ${ }^{2}$
}

${ }^{1}$ Master Student, Department of Pediatric Dentistry, Faculty of Dentistry, Tishreen University, Lattakia, Syria.

${ }^{2}$ Assistant Professor in the Department of Pediatric Dentistry, Head of the Department of Pediatric Dentistry, Faculty of Dentistry, Tishreen University, Lattakia, Syria.

\section{Abstract}

Oral mouthwash are good alternatives to lotions in chemical composition, like chlorhexidine. because of this, there is an increase in interest in natural alternatives such as honey and propolis, which have proven their effectiveness over time.

Aim: study effect of oralwashes of honey $50 \%$, chlorhexidine $0.12 \%$ and propolis $5 \%$ on lactobacillus .

Materials and Methods: the sample included 60 syrian children (30 males - 30 females), between (6-12) years. This study continued from September 2020 until February 2021, a saliva smear was taken for each child Before oral washing with research materials and swab after oral rinsing using $10 \mathrm{ml}$ of solution for 30 seconds, then cultivate it in the laboratory where it is grown on agar MRS medium and conducting a count of the results and comparing the averages before and after and the effect of each substance on the lactobacillus bacteria.

Results: after one minute of using the mouthwashes, the decrease rate in lactobacillus bacterial colony count was statistically significant in the chlorhexidine mouthwash as it was $80.55 \%$, in the propolis mouthwash it was $77.34 \%$, and in the honey mouthwash it was $61.90 \%$.

Conclusion: This study demonstrated the efficacy of oral chlorhexidine, propolis and honey mouthwashes on lactobacillus where the largest decrease effect was in chlorhexidine, then propolis, then honey, This indicates that the three substances are effective in reducing lactobacillus, which is recommended to use them when needed to reduce lactobacillus and to reduce dental caries.

Keywords: Mouthwashes; Lactobacillus; Honey; Propolis; Chlorhexidine.

\section{Introduction}

Oral cavity contains more than 500 endemic bacterial group naturally [1], Streptococcus mutans is one of the most important types of germs that cause dental caries. In association with Lactobacilli, these species are considered important pathogens in dental diseases [2].

Lactobacillus is a aerobic Gram-positive bacteria that has a straight or curved rod-shaped elongated cylindrical shape and ranges from 2-10 microns in length [3], It was previously believed that Lactobacillus is the main cause of dental caries, as it produces large quantities of acids when sugars are present, as it acid-producing such as Streptococcus, and it can survive even when the $\mathrm{pH}$ level is low [4], And the presence of high levels of them creates an appropriate environment for the development of dental caries [3].

Twetman and Grindef jord 1999 mentioned that there is an important relationship for Lactobacillus in the incidence of tooth decay, as the number of Lactobacillus increases with the increase in the number of decayed teeth.[2], This was confirmed by $\mathrm{Ny}$ lander et al. (2001), and added that these bacteria are the key in the process of tooth decay in association with S.mutans [5].

Oral washes are good alternatives to lotions of chemical composition like chlorhexidine, and because of this there has been an increase in interest in natural alternatives such as honey and propolis, which have proven their effectiveness over time, Oral

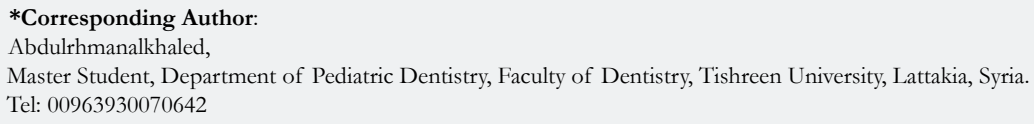

Citation: Abdulrhmanalkhaled, Faekbadr. Study Effect of Chlorhexidine - Honey and Propolis on Lactobacillus in Children. In Vitro Study. Int J Dentistry Oral Sci. 2021;8(10):47694773. doi: http://dx.doi.org/10.19070/2377-8075-21000967

Copyright: Abdulrhmanalkhaled ${ }^{\circ} 2021$. This is an open-access article distributed under the terms of the Creative Commons Attribution License, which permits unrestricted use, distribution and reproduction in any medium, provided the original author and source are credited. 
washes are one of the most important supportive treatments that have been used for decades to inhibition oral pathogenic bacteria that accumulate directly in the mouth and on perioral tissues that are not inhibited by systemic antibiotics. [6]

For a long time, chlorhexidine has been the most widely used mouthwash for reducing plaque and gingivitis, and there is no difference between an alcohol-based or a water-based lotion. It is considered the gold standard is among the mouthwash. [7], Chlorhexidine is a broad-spectrum biocide agent. It is highly effective against bacteria and fungi. It has a bactericidal and bacteriostatic effect. It is considered the first gold standard compared to other similar products due to its effectiveness and effect [8].

Propolis or what is known as bee gum or glue is a natural resinous substance that bees collect from the buds and parts of the plant, mixed with bee enzymes, pollen and wax. It has a complex formula with a wide range of antibacterial, antiviral, antifungal and antioxidant effects [9], Propolis is considered a pathogen killer and its high viscosity prevents foreign bodies from entering the beehive [10].

Propolis has important uses in dentistry and preventive dentistry, as studies in this field have shown the protective ability of propolis extracts when used to reduce the amount of bacterial plaque, thus reducing exposure to dental caries [11], While Drago et al. 2007 study showed that propolis reduced the number of germs that attach to the oral mucous membrane [12].

Barrientos et al 2013, confirmed the promising efficacy of propolis in the prevention of dental caries and some diseases of the oral cavity, when they demonstrated the bio-efficacy of the ethanoli extract and metanoli of the Chilean propolis samples against the bacteria that cause caries like, Streptococcus sobrinus, and Streptococcus mutans [13].

Honey is a natural, viscous, sweet-tasting food compound whose color ranges from light brown to dark resulting from the collection of nectar flowers or sugar secretions from some trees by bees and the addition of compounds to it that these bees secrete and then keep in the hexagonal eyes in Beehive [14], It was also used in ancient Chinese medicine in the treatment of diseases of the lung and large intestine, and it was used in Indian medicine in cleaning and treating open and infected wounds, eye diseases, coughing, diabetes, obesity and asthma [15].

Honey has antibacterial activity which is proven as honey is a broad-spectrum inhibitor of many types of bacteria , including aerobic and anaerobic bacteria, gram positive and negative, as one laboratory study showed that methanol, ethanol, and ethyl acetate extracted from honey showed positive antibacterial activity, Gram-negative bacteria(Staphylococcus aureus, Bacillus subtilis, Bacillus cereus, Enterococcus faecalis) and against Gram-negative bacteria( Escherichia coli, Pseudomonas aeruginosa, Salmonella typhi).[16], And one of the in vitro study results proved that honey was more effective in inhibiting plaque bacteria than other antibacterials used in fixed orthodontic patients [17], Tanzer et al. 2001 found that lactobacillus actively contributes to dental caries, but its role in the initiation of carious lesions has not yet been confirmed.[18]

\section{Materials and Methods}

Aim of study : Study of the effect of mouthwashes chlorhexidine $0.12 \%$ - honey $50 \%$ - propolis $5 \%$ on lactobacillus in children.

The study included 60 syrianchildren (30 males - 30 females), between (6-12) years, who had good oral health and did not suffer from: gingivitis, wear fixed or movable braces, and take antibiotics, This study continued from September 2020 until February 2021.

Inform consent was taken from the volunteers before starting the study according to a special form designed for the research that includes details of the research and the materials used in the research. The ethical approval was carried out according to the protocol followed by the Scientific Research Authority in the Syrian Arab Republic and at Tishreen University.

We used local products that are widespread in pharmacies. The children were divided into 3 groups, each group containing 20 children ( 20 chlorhexidine - 20 honey - 20 propolis).

We chose the concentration of honey $50 \%$ [19], the concentration of chlorhexidine $0.12 \%[20,21]$, and the concentration of propolis 5\% [22].

\section{- Saliva collection mechanism:[23]}

The child was brought to the clinic and the guardian requested the following:

1. Avoid food with a high content of acids and sugars 60 minutes before work in order to cause it to reduce the $\mathrm{pH}$ of saliva, which leads to an increase in bacterial growth.

2. Avoid foods and drinks containing caffeine for 12 hours before work.

3. That the sample be collected between 9 - 12 p.m.

4. Emphasis on not brushing the teeth on the same day in order to preserve the oral flora and not to have bleeding that affects the accuracy of reading the results.

5. Do not use any oral rinse or paste containing chlorhexidine 7 days before the start of the clinical procedures.

A first saliva sample was taken before using rinsing by using a sterile salivary swab for this procedure. The swab included passing the swab head over the vestibular surfaces of the teeth, the palate, the floor of the mouth, and the vestibule of the cheek. Then , the child was asked to rinse his mouth with solution using $10 \mathrm{ml}$ of solution for a period of time (30) seconds, After that, we took a second swab for the child, similar to its procedures for the first one, and the child's data were recorded on it (name - age - gender swab before / after) on each cotton swab and sent to the bacterial culture laboratory at Hama National Hospital - Hama city - syria, to start the laboratory work procedures.

- Chlorhexidine sample ( 20 children )

The product used is a $0.12 \%$ chlorhexidine solution ready for use, produced by a national company.

- Propolis sample ( 20 children)

The product used is a $5 \%$ propolis solution ready for use, produced by a national company 
- Honey sample ( 20 children )

The honey was $100 \%$ concentrated from the packing of a national company. We drew $5 \mathrm{ml}$ of honey and added it to $5 \mathrm{ml}$ of distilled water in a sterile sample collection package, and we mixed it and then gave it to the child to rinse with it.

Procedures for bacterial culture in the laboratory:

Cultivation media: Medium of lactobacillus (Man, Rogosa and sharp) MRS agar.[24]

\section{Sampling extension:}

We dilate the saliva samples in two stages to reduce the bacterial load for ease of counting, provided that the real concentration of germs is calculated later as follows:

\section{Stage one:}

Use of 10000 microliter $(10 \mathrm{ml})$ of salin by disposable one use syringe and put it in the glass tube. Then, we remove 100 micron. Thus, we get 9900 microliter in the tube. Then we add 100 micron of the saliva sample by micropipett. Finally we get dilate of saliva sample in $1 / 100$ radio; $10-2$. Then we mixed the homogenous dilate saliva sample on viberator for 30 seconds.

\section{Stage two:}

Repeate the previous stages but by adding 100 microliter of dilate solution to 9900 microliter from the saline in the other glass tube and the ratio became $1 / 10000$ and then repeate this homogenoue process by viberator.

Culture method: we take 10 microliter of dilate solution by micropipette. And then we spread it on the surface of culture media in Petri dish by sterilize platin loop tool in way that we get a distinct bacterial colony. And placed upside down within the incubator At $37^{\circ} \mathrm{C}$ for 48 hours in the presence of $5-10 \%$ of carbon dioxide.

Colonies counting: we count the colonies by using An Electron microscope, After the colonies counting is complete. This number presents the number of colonies in 10 dilate microliter. Thus , we multiply this number with 10000 which is the dilation ratio then we divide the number by 1000 to get the final number of bacterial colonies in $\mathrm{ml}(\mathrm{CFU} / \mathrm{ml})$.

To determine the shape of the lactobacillius, we apply Gram staining to an isolated colony according to the attached package instructions, Then we examine the color smear with an optical microscope after adding a drop of cedar oil, Some colonies appear as cocci or fungi, while the other part appears as bacilli or smooth surface Gram-positive coccobacilli, which are lactobacillius.

Statistical analysis: The data were analyzed using the statistical analysis program SPSS, version 13.00 , at a confidence level of 95\% ( $\mathrm{P}<0.05)$.

We used Paired sample T test to compare the variable means of the values of the studied variables.

\section{Results}

Table No. (1) shows descriptive statistical measures of the number of lactobacillius among the 60 patients $(20$ patients in each group), while Fig. No. (1) shows the arithmetic averages of the number of lactobacillius in the research patients.

Table No. (2) shows the results of using Paired Samples T Test when comparing the arithmetic means of the number of lactobacillius in each patient group before and after the experiment.

Table No. (3) shows the percentages of the amount of decrease in number of lactobacillius between the two times (before using the substance and after using the substance) between the three

Table 1. Statistical measures of the number of lactobacillius in the research patients.

\begin{tabular}{|c|c|c|c|c|c|c|}
\hline \multirow{2}{*}{ Material } & \multirow{2}{*}{ Sample } & Studied variables & mean & SD & $\begin{array}{c}\text { minimal } \\
\text { value }\end{array}$ & $\begin{array}{c}\text { max } \\
\text { value }\end{array}$ \\
\hline \multirow{2}{*}{ honey } & \multirow{2}{*}{20} & number of lactobacillius before using honey & 168.1 & 37.45 & 99 & 213 \\
\cline { 3 - 8 } & & number of lactobacillius after using honey & 64.05 & 14.25 & 38 & 83 \\
\hline \multirow{2}{*}{ propolis } & \multirow{2}{*}{20} & number of lactobacillius before using propolis & 160.9 & 51.42 & 101 & 289 \\
\cline { 3 - 8 } & & number of lactobacillius after using propolis & 31.3 & 11.73 & 23 & 66 \\
\hline \multirow{2}{*}{ chlorhexidine } & \multirow{2}{*}{20} & number of lactobacillius before using chlorhexidine & 160.9 & 44.65 & 100 & 255 \\
\cline { 3 - 8 } & & number of lactobacillius after using chlorhexidine & 31.3 & 9.61 & 14 & 49 \\
\hline
\end{tabular}

Table 2. Results of using Paired Samples T Test when comparing the arithmetic means of the number of lactobacillius before and after the experiment.

\begin{tabular}{|c|c|c|c|c|c|c|c|}
\hline Materials & \multicolumn{2}{|c|}{ Comparisons } & $\begin{array}{c}\text { difference between } \\
\text { arithmetic means }\end{array}$ & $\begin{array}{c}\text { T } \\
\text { Test value }\end{array}$ & df & $\begin{array}{c}\text { P- } \\
\text { value }\end{array}$ & description \\
\hline honey & $\begin{array}{c}\text { number of lactobacillius before using honey - } \\
\text { number of lactobacillius after using honey }\end{array}$ & Pair 1 & 104.05 & 19.26 & 19 & 0 & $\begin{array}{c}\text { There are statistically } \\
\text { significant differences }\end{array}$ \\
\hline propolis & $\begin{array}{c}\text { number of lactobacillius before using propolis } \\
\text { - number of lactobacillius after using propolis }\end{array}$ & Pair 1 & 127.8 & 14.398 & 19 & 0 & $\begin{array}{c}\text { There are statistically } \\
\text { significant differences }\end{array}$ \\
\hline chlorhexidine & $\begin{array}{c}\text { number of lactobacillius before using chlor- } \\
\text { hexidine - number of lactobacillius after using } \\
\text { chlorhexidine }\end{array}$ & Pair 1 & 129.6 & 16.403 & 19 & 0 & $\begin{array}{c}\text { There are statistically } \\
\text { significant differences }\end{array}$ \\
\hline
\end{tabular}


experimental groups.

As for Figure No. (2), it shows the percentage values of the amount of decrease in number of lactobacilliusbetween the two times (before using the substance and after using the substance) between the three experimental groups.

\section{Discussion}

Germs have developed antibiotic-resistant strains . pharmaceutical factories found it difficult to develop new antibacterial agents to meet this new challenge due to the high costs of drug research, which prompted researchers to search for an alternative to lowcost natural materials. [25]

The saliva count is a reasonable indicator of a complete bacterial load in the oral cavity [26].

Reports showed honey efficacy against a broad spectrum of multi-resistant bacteria used as a substitute clinically demonstrated a promising industrial pharmaceutical products.(Zainol et al., 2013) We chose Blood Agar as a culture medium because its properties make it a comprehensive growth medium. [27, 28]

In this study, we chose the method of culture on solid nutrient media to study oral bacterial flora because this method allows for qualitative and quantitative evaluation, which allows for a count of microorganisms and this is called Colony Forming Units (CFU), $\mathrm{CFU}$ is the lowest number of germ cells a pair, chain, clusters, or complete colony that they are found on the surface of the agar and grow to form a colony that can be seen with the naked eye.

In this study the rate of bacterial decrease in the number of lactobacillius was statistically significant after one minute of using Mouth washes, Where it was in chlorhexidine mouth wash $80.55 \%$, in the propolis mouth wash it was $77.34 \%$, and in honey mouth wash it was $61.90 \%$ with statistical significant $\mathrm{p}<0.05$.

The results of this study showed that the three mouthwashes had an immediate and direct effect on the lactobacillus bacteria, as chlorhexidine had a higher direct efficacy in reducing the lactobacillus count, followed by the efficacy of propolis and then honey. The results of the current study regarding the antibacterial effect of honey mouthwashes are in agreement with the results of $\mathrm{Ru}-$ pesh and colleagues 2014 confirming the antibacterial properties of New Zealand honey mouthwashes. [29]

We also agreed with the results of the study of Elbaz and colleagues 2012, where the study compared New Zealand honey and Egyptian propolis extract on Streptococcus mutans and lactobacillius, and the study concluded that Egyptian propolis was superior to New Zealand honey in affecting the number of Streptococcus mutans and lactobacillius.[30]

The results of our study on the effect of honey on lactobacillius differed with the results of the Greenbaum and Aryana 2013 study, where they found that honey could cause an increase in the growth of lactobacillius, possibly due to the substitution of sugar

Table 3. The percentages of the amount of decrease in number of lactobacilliusbetween the two times (before using the substance and after using the substance) between the three experimental groups.

\begin{tabular}{|c|c|c|c|c|c|}
\hline materials & $\begin{array}{c}\text { number } \\
\text { of pa- } \\
\text { tients }\end{array}$ & $\begin{array}{c}\text { lactobacillius variable } \\
\text { value before using } \\
\text { the material }\end{array}$ & $\begin{array}{c}\text { lactobacillius variable } \\
\text { value after using the } \\
\text { material }\end{array}$ & $\begin{array}{c}\text { The amount } \\
\text { of decrease }\end{array}$ & $\begin{array}{c}\text { Reduc- } \\
\text { tion ratio } \\
\mathbf{\%}\end{array}$ \\
\hline Honey & 20 & 161.3 & 38.25 & 123 & $76.29 \%$ \\
\hline Propolis & 20 & 173.7 & 25.2 & 149 & $85.49 \%$ \\
\hline Chlorhexidine & 20 & 158.45 & 15.9 & 143 & $89.97 \%$ \\
\hline Total & 60 & 164.48 & 39.167 & 125 & $76.19 \%$ \\
\hline
\end{tabular}

Figure 1. Mean of the number of lactobacillius in the research patients.

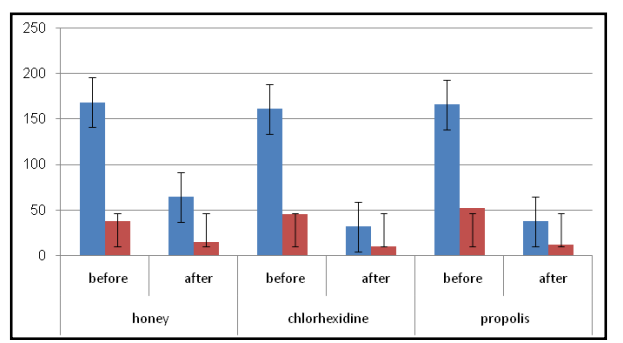

Figure 2. The percentages of the amount of decrease in number of lactobacillius between the two times (before using the substance and after using the substance) between the three experimental groups.

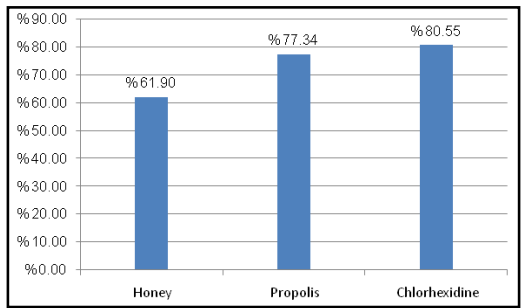


with honey in the manufacture of vanilla ice cream and the study of the medicinal effects of these ice creams. [31]

We disagreed with Lundström and Krasse regarding the effect of chlorhexidine on lactobacillius, as there was no significant effect in their study on it. This may be explained by the use of chlorhexidine gel 1\%. [32]

We agreed with the results of the Ahmadi study, as Hamadan honey showed a lowering of lactobacillus counts.[33]

\section{Conclusions}

1. This study demonstrated the effectiveness of chlorhexidine, propolis and honey mouthwashes on lactobacillus counts, where the largest share of the decrease was for chlorhexidine, then propolis, then honey.

2. The results of the current study showed the effectiveness of chlorhexidine $0.12 \%$ - honey $50 \%$ - propolis $5 \%$ in reducing the rates of oral bacterial load.

So, it is recommended to use chlorhexidine $0.12 \%$ - honey $50 \%$ propolis $5 \%$ as oral washes when we needed to reduce lactobacillus and to reduce dental caries.

\section{References}

[1]. Topazian RG, Goldberg MH, Hupp JR. Oral and maxillofacial infections. Elsevier Health Sciences; 2002.

[2]. Twetman S, Grindefjord M. Mutans streptococci suppression by chlorhexidine gel in toddlers. Am J Dent. 1999 Apr;12(2):89-91. Pubmed PMID: 10477989.

[3]. Badet C, Thebaud NB. Ecology of lactobacilli in the oral cavity: a review of literature. Open Microbiol J. 2008;2:38-48. Pubmed PMID: 19088910.

[4]. Balakrishnan M, Simmonds RS, Tagg JR. Dental caries is a preventable infectious disease. Aust Dent J. 2000 Dec;45(4):235-45. Pubmed PMID: 11225524.

[5]. Nylander A, Kumlin I, Martinsson M, Twetman S. Effect of a schoolbased preventive program with salivary lactobacillus counts as sugar-motivating tool on caries increment in adolescents. Acta Odontol Scand. 2001 Apr;59(2):88-92. Pubmed PMID: 11370756.

[6]. Heimall J, Bielory L. Defining complementary and alternative medicine in allergies and asthma: benefits and risks. Clin Rev Allergy Immunol. 2004 Oct;27(2):93-103. Pubmed PMID: 15576893.

[7]. Calvo-Guirado JL, Fernandez Dominguez M, Aragoneses JM, Martinez Gonzalez JM, Fernández-Boderau E, Garcés-Villalá MA, et al. Evaluation of new seawater-based mouth rinse versus chlorhexidine $0.2 \%$ reducing plaque and gingivitis indexes. a randomized controlled pilot study. Applied Sciences. $2020 \mathrm{Jan} ; 10(3): 982$.

[8]. Al Deeb L, Bin-Shuwaish MS, Abrar E, Naseem M, Al-Hamdan RS, Maawadh AM, et al. Efficacy of chlorhexidine, Er Cr YSGG laser and photodynamic therapy on the adhesive bond integrity of caries affected dentin. An in-vitro study. Photodiagnosis Photodyn Ther. 2020 Sep;31:101875. Pubmed PMID: 32534249.

[9]. Arbia A, Babbay B. Management strategies of honey bee diseases. Journal of Entomology. 2011;8(1):1-5.

[10]. Evans JD, Spivak M. Socialized medicine: individual and communal disease barriers in honey bees. J Invertebr Pathol. 2010 Jan;103 Suppl 1:S62-72. Pubmed PMID: 19909975

[11]. Więckiewicz W, Miernik M, Więckiewicz M, Morawiec T. Does propolis help to maintain oral health? Evid Based Complement Alternat Med. 2013;2013:351062. Pubmed PMID: 23365605.

[12]. Drago L, De Vecchi E, Nicola L, Gismondo MR. In vitro antimicrobial activity of a novel propolis formulation (Actichelated propolis). J Appl Microbiol. 2007 Nov;103(5):1914-21. Pubmed PMID: 17953601.

[13]. Barrientos L, Herrera CL, Montenegro G, Ortega X, Veloz J, Alvear M, et al. Chemical and botanical characterization of Chilean propolis and biological activity on cariogenic bacteria Streptococcus mutans and Streptococcus sobrinus. Braz J Microbiol. 2013 Oct 30;44(2):577-85. Pubmed PMID: 24294257.

[14]. Molan PC, Betts JA. Clinical usage of honey as a wound dressing: an update. J Wound Care. 2004 Oct;13(9):353-6. Pubmed PMID: 15517742.

[15]. Ali AT. Natural honey accelerates healing of indomethacin-induced antral ulcers in rats. Saudi medical journal. 1995 Mar 1;16:161-.

[16]. Mohapatra DP, Thakur V, Brar SK. Antibacterial efficacy of raw and processed honey. Biotechnol Res Int. 2011;2011:917505. Pubmed PMID: 21350671.

[17]. Patel RV, Thaker VT, Patel VK, Shukla P, Bhatnagar P, Patel A. In-vitro study of changing antibiotic sensitivity and resistance by honey on gingival inflammation during orthodontic treatment a preliminary report. Orthodontic CYBER j. 2010:3-8.

[18]. Tanzer JM, Börjesson AC, Laskowski L, Kurasz AB, Testa M. Glucose-sucrose-potassium tellurite-bacitracin agar, an alternative to mitis salivariusbacitracin agar for enumeration of Streptococcus mutans. J Clin Microbiol. 1984 Oct;20(4):653-9. Pubmed PMID: 6490852.

[19]. Chavan S, Kemparaj U, Tumpidi P, Pallavi N. Effect of honey against $S$. mutans and L. acidophilus: An in-vitro study. Journal of Chemical and Pharmaceutical Research. 2015;7(4):763-5.

[20]. Santos IR, Moreira AC, Costa MG, Castellucci e Barbosa Md. Effect of $0.12 \%$ chlorhexidine in reducing microorganisms found in aerosol used for dental prophylaxis of patients submitted to fixed orthodontic treatment. Dental Press J Orthod. 2014 May-Jun;19(3):95-101. Pubmed PMID: 25162572.

[21]. Cousido MC, Tomás Carmona I, García-Caballero L, Limeres J, Alvarez M, Diz P. In vivo substantivity of $0.12 \%$ and $0.2 \%$ chlorhexidine mouthrinses on salivary bacteria. Clin Oral Investig. 2010 Aug;14(4):397-402. Pubmed PMID: 19662444.

[22]. Airen B, Sarkar PA, Tomar U, Bishen KA. Antibacterial effect of propolis derived from tribal region on Streptococcus mutans and Lactobacillus acidophilus: An in vitro study. J Indian Soc Pedod Prev Dent. 2018 JanMar;36(1):48-52. Pubmed PMID: 29607839.

[23]. Hibel LC, Granger DA, Kivlighan KT, Blair C. Individual differences in salivary cortisol: associations with common over-the-counter and prescription medication status in infants and their mothers. Horm Behav. 2006 Aug;50(2):293-300. Pubmed PMID: 16682032.

[24]. Sutula J, Coulthwaite L, Verran J. Culture media for differential isolation of Lactobacillus casei Shirota from oral samples. J Microbiol Methods. 2012 Jul;90(1):65-71. Pubmed PMID: 22484087.

[25]. Zainol MI, Mohd Yusoff K, Mohd Yusof MY. Antibacterial activity of selected Malaysian honey. BMC Complement Altern Med. 2013 Jun 10;13:129. Pubmed PMID: 23758747.

[26]. Sullivan A, Borgström MK, Granath L, Nilsson G. Number of mutans streptococci or lactobacilli in a total dental plaque sample does not explain the variation in caries better than the numbers in stimulated whole saliva. Community Dent Oral Epidemiol. 1996 Jun;24(3):159-63. Pubmed PMID: 8871012.

[27]. Carl W. Oral manifestations of systemic chemotherapy and their management. Semin Surg Oncol. 1986;2(4):187-99. Pubmed PMID: 3330277.

[28]. Council on Dental Materials, I. and E.J.T.J.o.t.A.D. Association, Infection control recommendations for the dental office and the dental laboratory. 1988. 116(2): p. 241-248.

[29]. Rupesh S, Winnier JJ, Nayak UA, Rao AP, Reddy NV, Peter J. Evaluation of the effects of manuka honey on salivary levels of mutans streptococci in children: a pilot study. J Indian Soc Pedod Prev Dent. 2014 Jul-Sep;32(3):212-9. Pubmed PMID: 25001440.

[30]. Elbaz GA, Elsayad II. Comparison of the antimicrobial effect of Egyptian propolis vs New Zealand propolis on Streptococcus mutans and lactobacilli in saliva. Oral Health Prev Dent. 2012;10(2):155-60. Pubmed PMID: 22763595.

[31]. Greenbaum A, Aryana KJ. Effect of honey a natural sweetener with several medicinal properties on the attributes of a frozen dessert containing the probiotic Lactobacillus acidophilus.

[32]. Lundström F, Krasse B. Streptococcus mutans and lactobacilli frequency in orthodontic patients; the effect of chlorhexidine treatments. Eur J Orthod. 1987 May;9(2):109-16. Pubmed PMID: 3472888.

[33]. Ahmadi-Motamayel F, Hendi SS, Alikhani MY, Khamverdi Z. Antibacterial activity of honey on cariogenic bacteria. J Dent (Tehran). 2013 Jan;10(1):105. Pubmed PMID: 23724198 